ENCYCLOPEEDIE Encyclopédie berbère

BERBERE

$4 \mid 1986$

4 | Alger - Amzwar

\title{
Aliw (pl. Aliwen)
}

\section{S. Chaker}

\section{(2) OpenEdition}

Journals

Édition électronique

URL : http://journals.openedition.org/encyclopedieberbere/2448

DOI : 10.4000/encyclopedieberbere.2448

ISSN : 2262-7197

\section{Éditeur}

Peeters Publishers

\section{Édition imprimée}

Date de publication : 1 septembre 1986

Pagination : 529-530

ISBN : 2-85744-282-3

ISSN : 1015-7344

\section{Référence électronique}

S. Chaker, «Aliw (pl. Aliwen) », Encyclopédie berbère [En ligne], 4 | 1986, document A167, mis en ligne le 01 décembre 2012, consulté le 13 octobre 2020. URL : http://journals.openedition.org/ encyclopedieberbere/2448; DOI : https://doi.org/10.4000/encyclopedieberbere.2448

Ce document a été généré automatiquement le 13 octobre 2020

(c) Tous droits réservés 


\section{Aliw (pl. Aliwen)}

\section{S. Chaker}

1 Ce terme attesté en touareg sous les formes: Ahaggar : âléo / âliwen (Foucauld, III, p. 119), touareg méridional : aliw / aliwăn (Alojaly, p. 119), désigne en premier lieu « l'olivier sauvage » (Olea Laperrini, sp. nov., B.T.) dont on rencontre quelques spécimens en Ahaggar (quelques centaines à un ou deux milliers, en haute altitude, selon Foucauld).

2 Ce mot est certainement apparenté au grec elaiwā ( olivier »)/elaiwon ( huile d'olive ») et au latin oliua, oleum, olea. Mais il ne s'agit pas nécessairement d'un emprunt à l'une de ces langues car les dénominations grecques et latines n'appartiennent pas au fonds lexical indo-européen et les spécialistes s'accordent à les considérer comme provenant du fonds « méditerranéen » pré-indo-européen (Meillet, 1975, p. 302-303). 
Olea laperrini dans le Haut Mertoûtek (photo M. Gast).

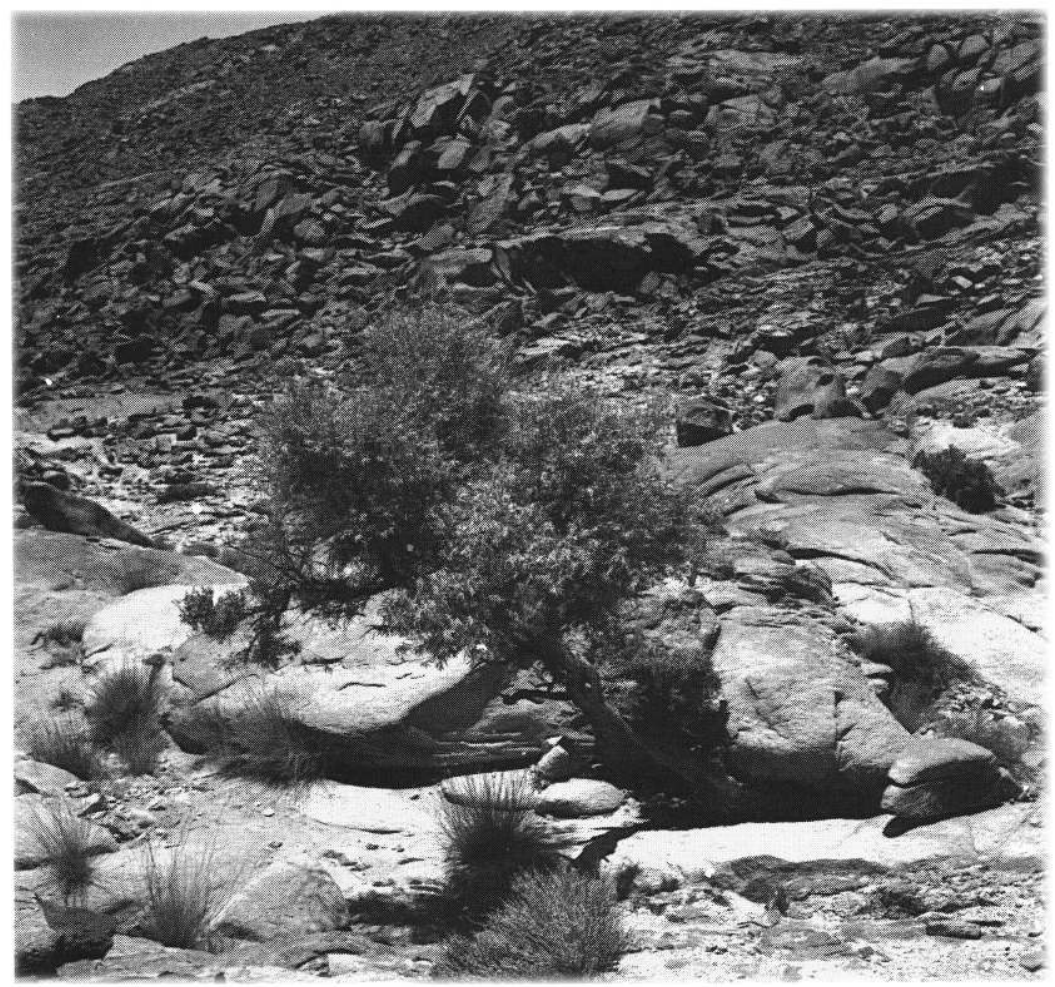

3 Le pluriel āliwen désigne en outre un rythme poétique très particulier utilisé dans les chants rituels interprétés par les femmes lors des cérémonies de mariages. Āliwen désigne également ces chants eux-mêmes. Les Āliwen constituent un stock figé de vers très anciens, peu nombreux qui seraient - selon Foucauld - originaires de l'Ajjer.

4 On constate ainsi avec intérêt que le pluriel āliwen, "les oliviers / les olives » - ici certainement symbole de fécondité - sert à dénommer en touareg des chants du mariage.

5 Il s'agit là sans doute d'une de ces nombreuses traces de l'origine méditerranéenne des populations touarègues.

\section{BIBLIOGRAPHIE}

ALOJALY Gh., Lexique touareg-français, Copenhague, 1980.

FOUCAUld Ch. (de), Dictionnaire touareg-français, (4 vol. ), Paris, 1951-51.

FOUCAULD Ch. (de), Poésies touarègues. Dialecte de l'Ahaggar, I, Paris (p. IX et XXI), 1925.

MEILLET A., «A propos des noms du vin et de l'huile, Linguistique historique et linguistique générale, Paris, p. 297-304, 1975. 
PRASSE K.-G., Manuel de grammaire touarègue, I-III, Copenhague, (p. 126 et sq., notamment 133), 1972.

INDEX

Mots-clés : Linguistique 